\title{
Oral health in children and adolescents with juvenile idiopathic arthritis - a systematic review and meta-analysis
}

Marit S. Skeie ${ }^{1,2^{*}}$ D, Elisabeth G. Gil ${ }^{1}$, Lena Cetrelli ${ }^{2}$, Annika Rosén ${ }^{1,3}$, Johannes Fischer ${ }^{1}$, Anne Nordrehaug Åstrøm', Keijo Luukko', Xieqi Shi ${ }^{1,4}$, Astrid J. Feuerherm², Abhijit Sen ${ }^{2,5}$, Paula Frid ${ }^{6,7,8}$, Marite Rygg ${ }^{9,10}$ and Athanasia Bletsa ${ }^{11,1}$

\begin{abstract}
Background: Observational studies examining the association between oral health and juvenile idiopathic arthritis (JIA) among children and adolescents have reported inconsistent findings. The aims of this systematic review and meta-analysis were to ascertain a potential difference in oral health and oral health-related quality of life (OHRQoL) among children and adolescents with JIA and healthy peers, and to assess the association of prevalence of oral diseases/conditions, temporomandibular disorders (TMD), including temporomandibular joint (TMJ) diseases, in relation to activity and severity of JIA.
\end{abstract}

Method: Medline Ovid, Embase, CINAHL, SweMed+ and Cochrane Library were searched up to 25 November 2018. All articles published in English, German and Scandinavian languages focusing on children and adolescents with JIA and without JIA in relation to oral health measures, were considered. Two authors independently evaluated observational studies for inclusion. The study quality was assessed using modified Newcastle Ottawa Scale. Metaanalysis was performed for studies focusing on dental caries as an outcome.

Results: Nineteen articles met the inclusion criteria, covering a range of oral diseases/conditions and OHRQoL. Eighteen studies had cross-sectional design. No mean difference of dmft/DMFT indices (decayed/missed/filled teeth) was observed between the IIA - and healthy group. None of the oral health measures including dental erosive wear, enamel defects, dental maturation and OHRQoL, indicated better oral health among children and adolescents with JIA compared to healthy group. However, periodontal conditions and TMD were more predominant among children and adolescents with JIA compared to healthy peers.

Conclusions: Based on the cross-sectional studies, periodontal diseases and TMD were found to be more frequent in children and adolescents with JIA compared to healthy peers. Furthermore, more high-quality studies with large sample size are needed before we infer any concrete conclusion regarding the association between the prevalence of oral and TMJ diseases or oral conditions in relation to activity and severity of JIA.

Keywords: Stomatognathic diseases, Temporomandibular joint disease, Arthritis juvenile rheumatoid, Juvenile idiopathic arthritis, Child, Adolescent

\footnotetext{
* Correspondence: marit.skeie@uib.no

'Department of Clinical Dentistry, Pediatric Dentistry, The Faculty of

Medicine, University of Bergen, Norway, Årstadveien 19, N-5009 Bergen,

Norway

${ }^{2}$ Center for Oral Health Services and Research, Mid-Norway (TkMidt),

Trondheim, Norway

Full list of author information is available at the end of the article
}

(c) The Author(s). 2019 Open Access This article is distributed under the terms of the Creative Commons Attribution 4.0 International License (http://creativecommons.org/licenses/by/4.0/), which permits unrestricted use, distribution, and reproduction in any medium, provided you give appropriate credit to the original author(s) and the source, provide a link to the Creative Commons license, and indicate if changes were made. The Creative Commons Public Domain Dedication waiver (http://creativecommons.org/publicdomain/zero/1.0/) applies to the data made available in this article, unless otherwise stated. 


\section{Background}

Juvenile idiopathic arthritis (JIA) is a common chronic rheumatic condition, affecting around 1 in 1000 children under the age of 16 years [1,2]. The incidence and prevalence of JIA varies across different studies globally, but by pooling data from several studies, it is estimated that around 60,000 children below 16 years are affected in Europe, with an estimated incidence of around 7000 new cases each year [3]. The incidence in the Nordic countries including Norway is among the highest in the world [4]. JIA comprises a group of distinct clinical entities of unknown aetiology, characterized by joint inflammation with symptoms persisting for more than six weeks and onset before 16 years of age [5]. Currently, it is classified according to the International League of Associations of Rheumatology (ILAR) as systemic arthritis, polyarthritis (Rheumatoid factor (RF) negative or positive), oligoarthritis (persistent or extended), enthesitisrelated arthritis, psoriatic arthritis and undifferentiated arthritis [5].

Long-term inflammation and use of anti-inflammatory drugs, such as corticosteroids, may cause disturbances in growth and pubertal development, overall bone maturation, and eventually the development of osteopenia with low bone mineral content and low mineral density. These consequences are found to be associated with the duration of active JIA and severity [6] and are more frequent in individuals with early-onset JIA [7].

Overload of bacteria is considered as a possible trigger of rheumatic arthritis (RA) in adults [8]. This means that the oral cavity, one of the most bacteria colonised parts of the body and hosting nearly 800 species of bacteria [9], should be kept free from oral diseases. When the oral microbiota [10] shifts from balance to imbalance (dysbiosis), e.g. during rapid caries development, bacteria might pass through exposed dentine, pulp or periapical bone to the bloodstream [11]. In case of plaque accumulation at gingival margins or during ongoing gingivitis or periodontitis, bacteria might pass the blood stream through periodontal pockets, or through the oral mucosa directly if there is oral mucositis or ulcer. In patients with RA, dysbiosis has been detected in the gut and oral microbiomes (dental and saliva microbiome) and has been found to be correlated with clinical measures of RA status and to be altered compared with healthy individuals [12].

Individuals with JIA may be subjected to unfavourable underlying oral health determinants. If JIA reduces functional ability of the upper limbs, effective tooth brushing and plaque removal will be difficult. Plaque removal might also be impeded in children with JIA with restriction in mouth opening [13]. When JIA is accompanied by impaired masticatory function, consumption of softer and more sugary foods in small amounts might be more convenient [14]. Frequent and long-term intake of liquid oral medication with sugary or acidic content has previously been reported in children with JIA [15], but today sugar-free alternatives exist [16], and there is reason to believe that such intake is more rare. Knowledge of intra-oral adverse effects and frequency of side effects of modern long-term administration of anti-rheumatic drugs, is hitherto scarce.

Temporomandibular disorder (TMD) is an umbrella term including Temporomandibular joint (TMJ) involvement as well as localized pain in the masticatory muscles, decreased mouth opening and chewing ability, pain associated with mandibular movement during eating, chewing or yawning, and comorbidities such as earache and headache [7]. A high proportion of children with JIA might have involvement of the TMJ during disease course [17]. The consequences of local inflammation in the TMJs may involve local growth disturbances and as a consequence impaired mandibular growth [18]. Development of malocclusion and facial deformities such as micro- or retrognathia, are later scenarios associated with established permanent sequelae in the TMJ [7]. To identify TMJ arthritis early enough to prevent permanent growth disturbances and joint damage, it is important to recognize all clinical symptoms associated with JIA involvement. A challenge is that TMJ arthritis might evolve without or with TMD symptoms, especially in the youngest children who are unable to communicate and localize their pain adequately [7]. Thus, early detection of TMD by imaging signs of inflammation in the joints is essential.

In 2016, the key part of Vision 2020 [19] was approved, including an upgraded definition of oral health which is estimated to be multifaceted and to include different attributes of oral health. The new definition not only includes disease and condition status, but also underlying determinants, moderating factors, overall health and well-being. Thus, the ability to speak, smile, smell, taste, touch, chew, swallow and express emotions, functioning without feeling pain or discomfort, are integrated components in oral health. Children and adolescents with TMJ arthritis, may experience reductions in one, some or all these abilities, resulting in both reduced quality of life (QoL) [20] and reduced oral health-related quality of life (OHRQoL) [21]. For the group of children and adolescents with JIA, documentation of reduced OHRQoL due to oral diseases restricted to the oral cavity, e.g. dental caries, dental erosion, and not including jaw symptoms, is sparse.

Whether children and adolescents with JIA have a heavier burden of oral conditions and as a consequence, experience reduced OHRQoL, is not clearly established. For this reason, the aims of this systematic review were to gain reliable information on the following research questions; 
1. Is oral health and oral health-related quality of life poorer among children and adolescents with JIA than among their healthy peers?

2. Does the activity and severity of JIA have any impact on the prevalence of oral and TMJ diseases or oral conditions?

\section{Methods}

A systematic electronic literature search in the five main databases, Medline Ovid, Embase, CINAHL, SweMed+ and Cochrane Library, took place during the period 24.11.2017-01.12.2017. The search was later updated 25 Nov 2018. The search consisted of a combination of free text words and subject headings (i.e. MeSH, Emtree). In addition, manual searches in the reference lists of included articles were conducted. The details of search terms used for the different databases are presented in Additional file Table 1: S1.

\section{Inclusion and exclusion criteria}

This review primarily reports articles restricted to peerreviewed journal articles published in English, German, Norwegian, Swedish or Danish during the period 1998 through 25 Nov 2018 covering children and adolescents' age groups. Randomised controlled trials (RCTs), controlled clinical trials (CTs), cohort studies, crosssectional studies or case-control studies were included. The exclusion criteria were systematic reviews, metaanalyses, case reports, conference publications and grey literature. Grey literature was excluded as this type can vary considerably and often be affected by low standard of quality, review and production. In addition, studies lacking comparing groups (i.e. groups without JIA) were excluded for the analyses purpose. Lastly, as another systematic review is planned, articles mainly addressing saliva variables and orthodontic considerations in children and adolescents with JIA, were excluded.

\section{Search strategy}

PRISMA [41] was followed as a guide for reporting this systematic review and meta-analysis. The levels followed in the literature search were as follows: 1) title and authors, 2) abstracts, and 3) full text. For abstracts decided to be within the scope of interest, full-text articles were read. Two reviewers (MSS and AB) independently evaluated studies for inclusion, and studies were selected after reading abstracts, and selected full-text articles. When abstract selection was not straightforward and the reviewers were in doubt, full-text articles were re-read by both reviewers and resolved by discussion. A flow diagram is presented as Additional file 5: Figure. S1.

\section{Outcomes}

Oral health and OHRQoL were assessed among children and adolescents with JIA and among those without JIA, and these examination data constituted the outcomes. Any outcome measures with information outside the scope of this review, but within included articles, are not mentioned. An overview of key information from the final evaluation is shown in Tables 1 and 2 in a similar way as a previous systematic review [74].

\section{Qualitative assessment}

Central themes and topics from the PICOS (participants, interventions, comparators, and study design) approach were only to some extent extracted in Tables 1 and 2 as an intervention was not the focus. The characteristics considered important for the evaluation of reliability and validity, were study design, level of control matching, exclusion criteria, non-respondents, sample size, calibration procedures, number of examiners, documentation of JIA history (activity assessment, laboratory evaluation, medication), applied imaging type, and oral health diagnostic tools. MSS conducted the data extraction and checked by $A B$ for accuracy. Assessment of risk of bias was performed based on an adapted version of the Newcastle - Ottawa Scale (NOS) [75], which was further modified in support of this systematic review (Additional file 2: Table S2). Scoring was performed by two authors (MSS and $\mathrm{AB}$ ), but in case of discrepancies, a third author (AS) was consulted. The range of the scores was from 0 to 10 (low risk of bias = overall scores were $9-10$, medium risk of bias $=6-8$, high risk of bias $=0-5$ ). Summarized scores of each study are presented in Additional file 3: Table S3.

\section{Statistical analysis}

It was not possible to perform meta-analysis of oral health outcomes regarding oral hygiene (dental plaque and calculus accumulation), periodontal disease (gingivitis included), enamel defects, tooth calcification (dental maturation) disorders, TMJ arthritis, TMJ involvement, TMD, oral ulcerations, and OHRQoL. The reasons include inadequate sample size, poor study quality, use of inconsistent definitions of outcomes (e.g. periodontitis assessment) or studies that failed to report number of children and adolescents with JIA. Nevertheless, metaanalyses for dental caries was performed. Two separate meta-analyses were conducted using continuous outcomes: $\mathrm{dmft}$ score (decayed/missed/filled primary teeth) and DMFT score (decayed/missed/filled permanent teeth). We used random-effect model [76] to calculate pooled mean differences between $\mathrm{dmft} / \mathrm{DMFT}$ scores of children and adolescents with JIA and those without JIA. The articles that did not report dmft or DMFT score or standard deviation were excluded from this 
Table 1 Characteristics of the studies ( $n=19$ ), restricted to variables selected to be included in this review

\begin{tabular}{|c|c|c|c|c|c|}
\hline \# Study & Country & Age (years) & Sample size & Study design & Oral health parameters \\
\hline $\begin{array}{l}\text { Ahmed N et al. } \\
2004 \text { [22] }\end{array}$ & UK & $4-16$ & $\begin{array}{l}55 \text { JIA (34 girls) } \\
55 \text { No JIA }\end{array}$ & Cross-sectional & $\begin{array}{l}\text { Dental caries } \\
\text { Oral hygiene } \\
\text { Periodontal conditions } \\
\text { Enamel defect } \\
\text { TMJ dysfunction }\end{array}$ \\
\hline $\begin{array}{l}\text { Feres de Melo AR et al. } \\
2014 \text { [23] }\end{array}$ & Brazil & $6-12$ & $\begin{array}{l}36 \text { JIA (20 girls) } \\
36 \text { No JIA (19 girls) }\end{array}$ & Cross sectional & $\begin{array}{l}\text { Dental caries } \\
\text { Oral hygiene } \\
\text { Periodontal conditions }\end{array}$ \\
\hline Lehtinen A et al. 2000 [24] & Finland & $6-14$ & $\begin{array}{l}168 \text { JIA (95 girls) } \\
168 \text { No JIA (102 girls) }\end{array}$ & Cross-sectional & $\begin{array}{l}\text { Tooth calcification } \\
\text { (dental maturation) }\end{array}$ \\
\hline Leksell E et al. 2008 [25] & Sweden & $10-19$ & $\begin{array}{l}41 \text { JIA (29 girls) } \\
41 \text { No JIA(25 girls) }\end{array}$ & Cross-sectional & $\begin{array}{l}\text { Oral hygiene } \\
\text { Periodontal conditions } \\
\text { Oral ulcerations }\end{array}$ \\
\hline Miranda LA et al. 2003 [26] & Brazil & Adolescents & $\begin{array}{l}32 \text { JIA ( } 69 \% \text { girls) } \\
24 \text { No JIA ( } 50 \% \text { girls) }\end{array}$ & Cross-sectional & $\begin{array}{l}\text { Oral hygiene } \\
\text { Periodontal conditions }\end{array}$ \\
\hline Pugliese C et al. 2016 [27] & Brazil & Adolescents & $\begin{array}{l}35 \mathrm{JIA} \text { (all girls) } \\
35 \mathrm{No} J \mathrm{~A} \text { (all girls) }\end{array}$ & Cross-sectional & $\begin{array}{l}\text { Oral hygiene } \\
\text { Periodontal conditions }\end{array}$ \\
\hline Reichert S et al. 2006 [28] & Germany & $12-19$ & $\begin{array}{l}78 \text { JIA (58\% girls) } \\
75 \text { No JIA ( } 45 \% \text { girls) }\end{array}$ & Cross-sectional & $\begin{array}{l}\text { Oral hygiene } \\
\text { Periodontal conditions }\end{array}$ \\
\hline $\begin{array}{l}\text { Santos D et al. } \\
2015 \text { [29] }\end{array}$ & Brazil & $6-14$ & $\begin{array}{l}14 \text { JIA (77\% girls) } \\
15 \text { No JIA (48\% girls) }\end{array}$ & Cross-sectional & $\begin{array}{l}\text { Caries } \\
\text { Oral hygiene } \\
\text { Periodontal conditions } \\
\text { TMD } \\
\text { OHRQOL }\end{array}$ \\
\hline $\begin{array}{l}\text { Savioli C et al. } \\
2004 \text { [30] }\end{array}$ & Brazil & $4.7-20$ & $\begin{array}{l}36 \text { JIA (26 girls) } \\
13 \text { No JIA (9 girls) }\end{array}$ & Cross-sectional & $\begin{array}{l}\text { Caries } \\
\text { Oral hygiene } \\
\text { Periodontal conditions }\end{array}$ \\
\hline Welbury RR et al. 2003 [31] & UK & $\begin{array}{l}0-17 \text { (adults included } \\
\text { in the sample) }\end{array}$ & $\begin{array}{l}149 \text { JIA (107 girls) } \\
149 \text { No JIA (107 girls) }\end{array}$ & Cross-sectional & $\begin{array}{l}\text { Caries } \\
\text { Oral hygiene } \\
\text { Periodontal conditions }\end{array}$ \\
\hline Miranda LA et al. 2005 [32] & $\begin{array}{l}\text { Brazil } \\
\text { Sweden }\end{array}$ & Adolescents & $\begin{array}{l}38 \text { JIA } \\
29 \text { No JIA }\end{array}$ & Cross-sectional & $\begin{array}{l}\text { Oral hygiene } \\
\text { Periodontal conditions }\end{array}$ \\
\hline Miranda LA et al. 2006 [33] & Brazil & Adolescents & $\begin{array}{l}18 \text { JIA (9 girls) } \\
14 \text { No JIA (5 girls) }\end{array}$ & $\begin{array}{l}\text { Longitudinal } \\
\text { (2-yr-follow-up) }\end{array}$ & $\begin{array}{l}\text { Oral hygiene } \\
\text { Periodontal conditions }\end{array}$ \\
\hline Maspero C et al. 2017 [34] & Italy & $10-18$ & $\begin{array}{l}40 \mathrm{JIA} \\
20 \mathrm{No} J \mathrm{JA}\end{array}$ & Cross-sectional & $\begin{array}{l}\text { Oral hygiene } \\
\text { Periodontal conditions }\end{array}$ \\
\hline Al-Shwaikh H et al. 2016 [35] & Latvia & $<17$ & $\begin{array}{l}65 \text { JIA (45 girls) } \\
30 \text { No JIA ( } 24 \\
\text { girls): }\end{array}$ & Cross-sectional & TMJ destruction features \\
\hline Abdul-Aziez & Egypt & $7.5-17.0$ & $\begin{array}{l}20 \text { JIA (12 girls) } \\
10 \text { No JIA (6 girls) }\end{array}$ & Cross-sectional & TMJ inflammation \\
\hline \multicolumn{6}{|l|}{ OA et al. 2010 [36] } \\
\hline $\begin{array}{l}\text { Mohammed } Y \text { et al. } \\
2012 \text { [37] }\end{array}$ & Egypt & $8.5-17$ & $\begin{array}{l}40 \text { JIA (26 girls) } \\
10 \text { No JIA (6 girls) }\end{array}$ & Cross sectional & TMJ inflammation \\
\hline Leksel E et al. 2012 [38] & Sweden & $10-19$ & $\begin{array}{l}41 \text { JIA (29 girls) } \\
41 \text { No JIA ( } 29 \text { girls) }\end{array}$ & Cross-sectional & $\begin{array}{l}\text { Orofacial pain } \\
\text { TMJ }\end{array}$ \\
\hline Kobus A et al. 2017 [39] & Poland & $6-18$ & $\begin{array}{l}34 \text { JIA (21 girls) } \\
34 \text { No JIA (21 girls) }\end{array}$ & Cross-sectional & $\begin{array}{l}\text { Dental caries } \\
\text { Oral hygiene } \\
\text { Periodontal conditions }\end{array}$ \\
\hline Ley M et al. 2009 [40] & Germany & $7-17$ & $\begin{array}{l}64 \text { JIA (48 girls) } \\
\text { No JIA: Norms (healthy) } \\
\text { at same age }\end{array}$ & Cross-sectional & $\begin{array}{l}\text { Tooth calcification } \\
\text { (dental maturation) }\end{array}$ \\
\hline
\end{tabular}

meta-analysis. The heterogeneity between the studies were quantitatively assessed by the Q-test and $\mathrm{I}^{2}$ statistics [77]. $\mathrm{I}^{2}$ is the proportion of total variation explained by between-study variation. $\mathrm{I}^{2}$-values of $0,25,50 \%$ and $\geq$
75\% indicates no, low, moderate and high heterogeneity, respectively. Publication bias was assessed by inspection of funnel plots for asymmetry and using Egger's test [78] and Begg-Mazumdar test [79]. 


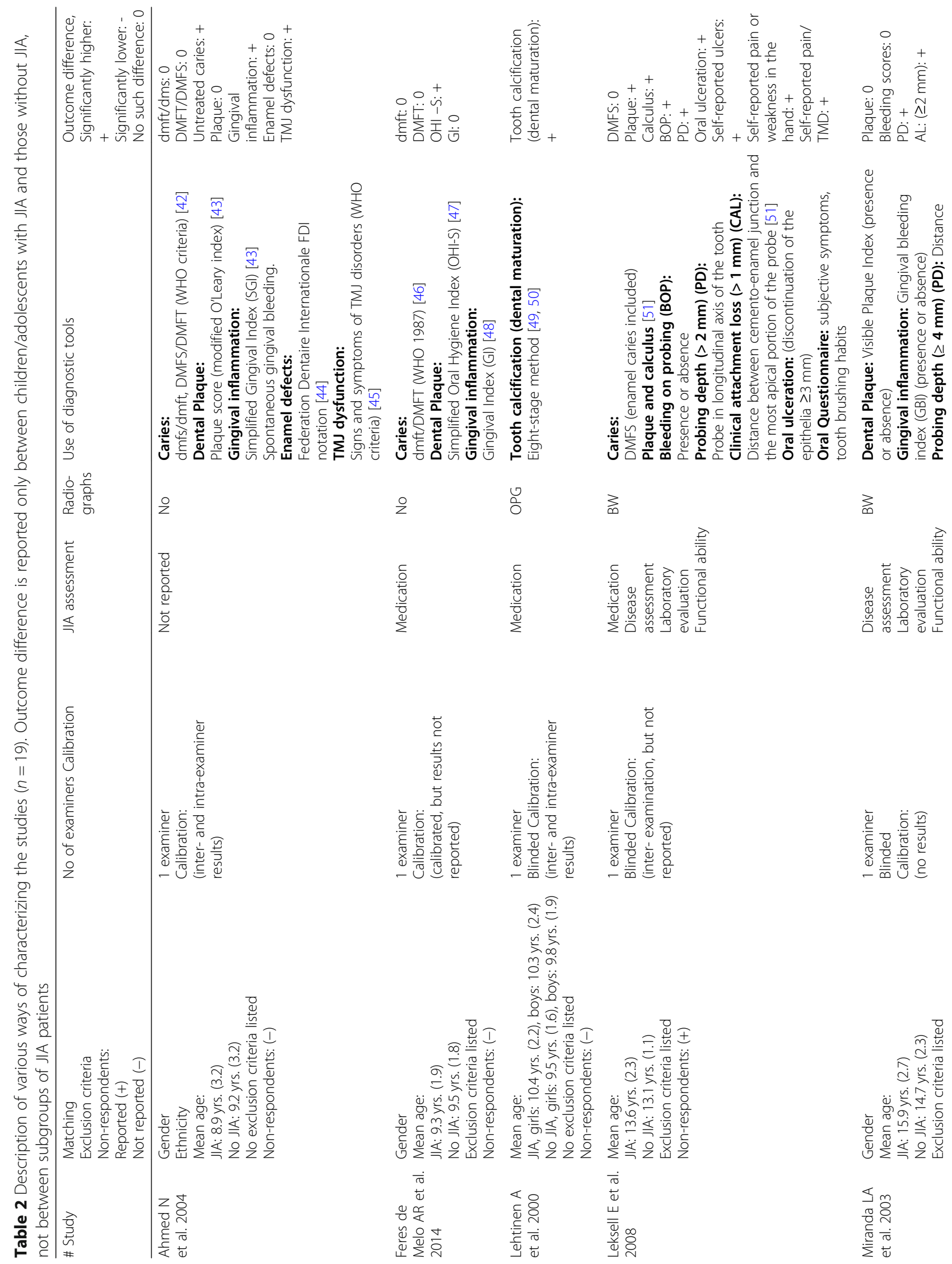




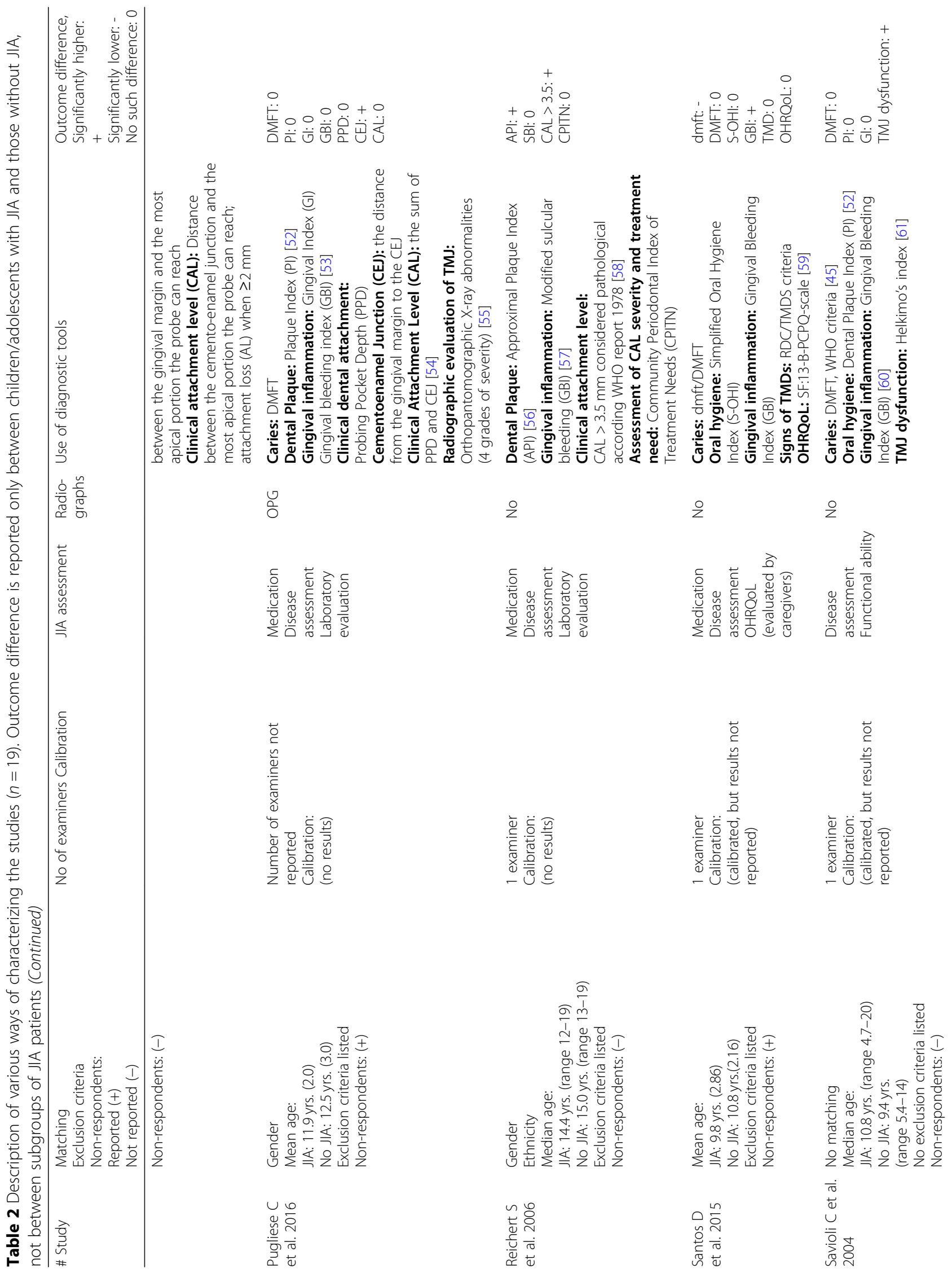




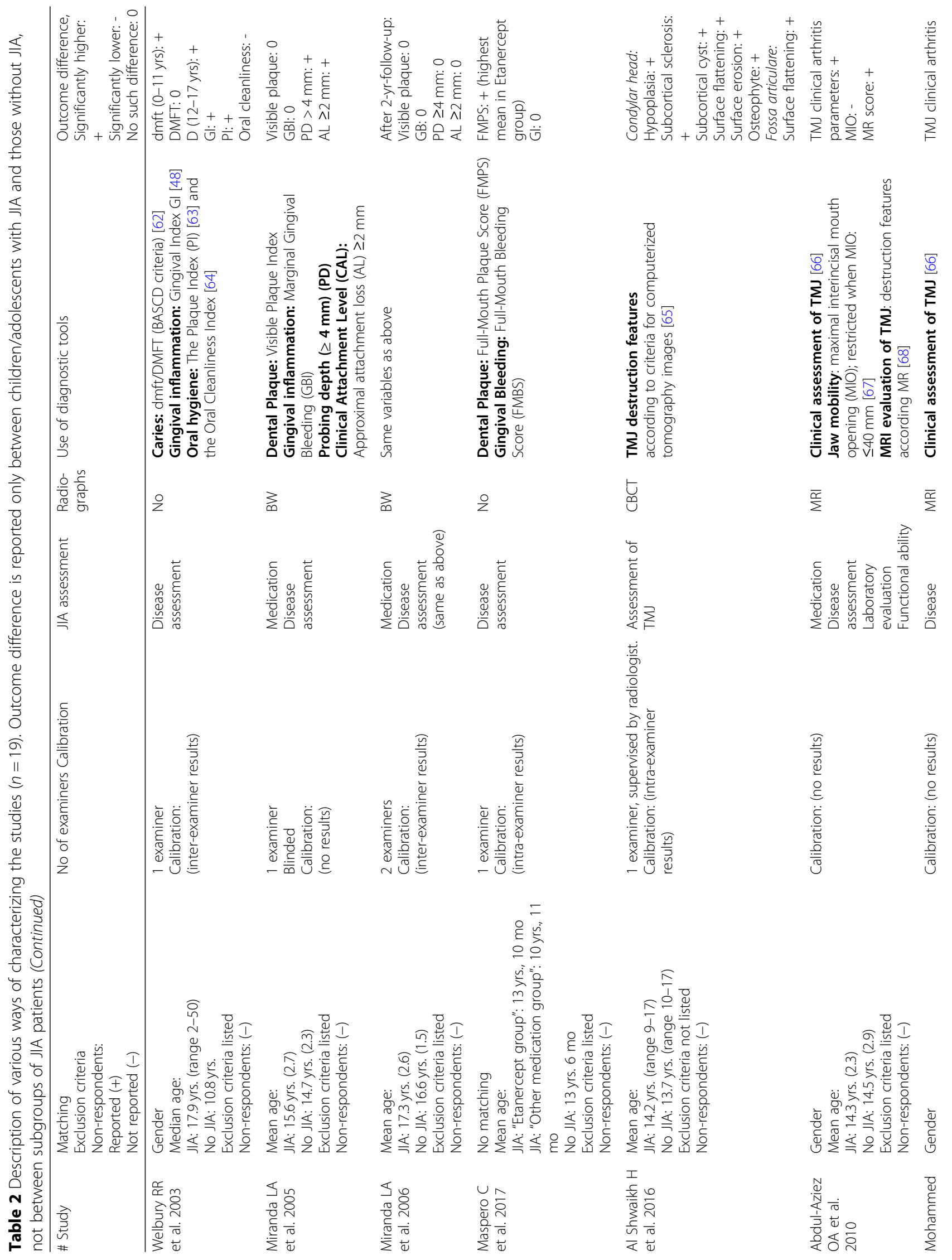




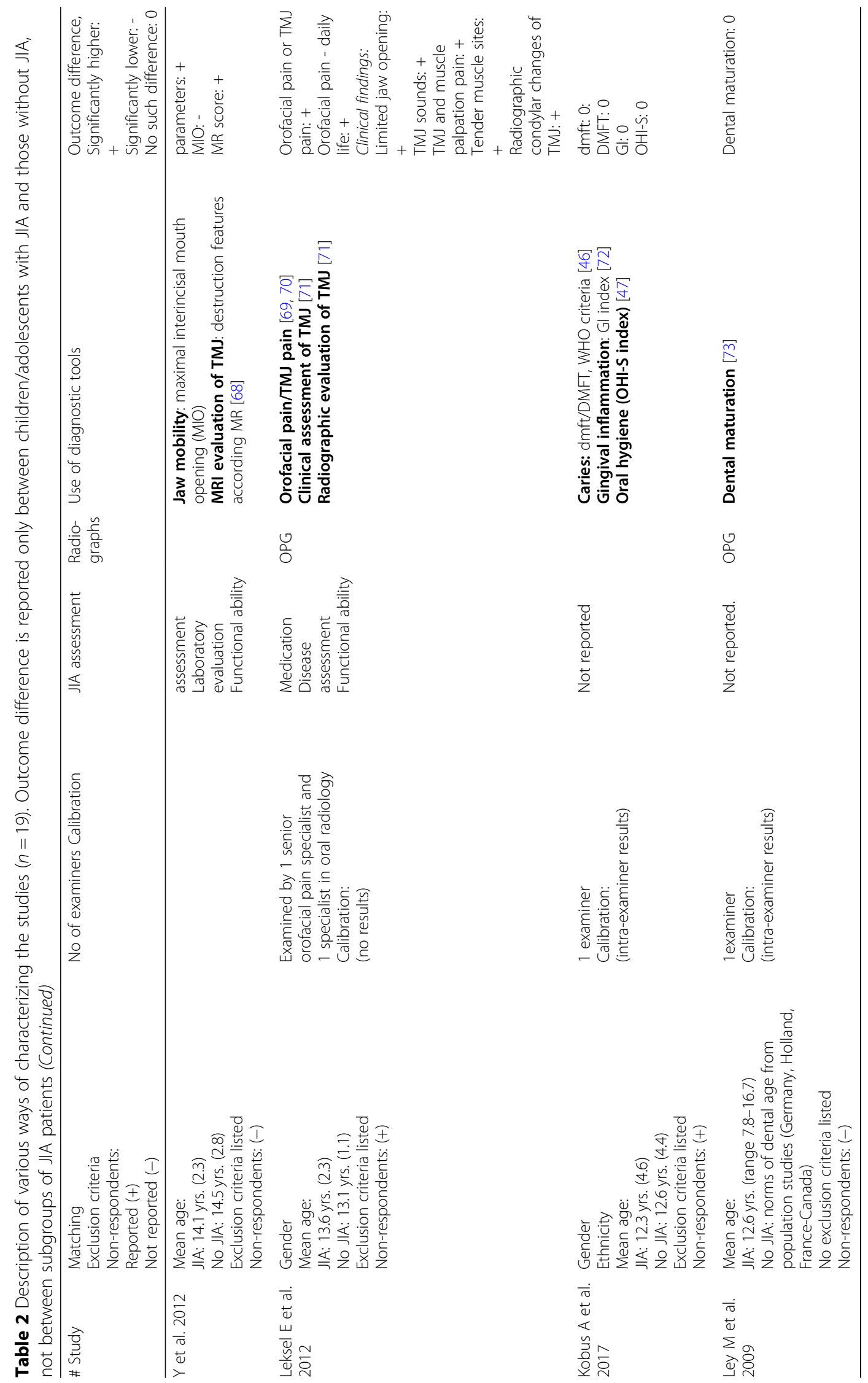


A two tailed $p<0.05$ was considered statistically significant. Statistical analyses were performed using Stata, version 15.0 software (StataCorp, Texas, USA).

\section{Results}

Nineteen articles met the inclusion criteria, ten from Europe and nine from countries outside Europe with Brazil in the lead, see Table 1. The age range of children and adolescents with JIA was from two to four years in two studies [22,31] and up to 20 years of age in one study [30]. Altogether, the included articles covered topics such as dental caries, oral hygiene (dental plaque and calculus accumulation), periodontal disease (gingivitis included), enamel defects, tooth calcification (dental maturation) disorders, TMJ arthritis, TMJ involvement, TMD, oral ulcerations, and OHRQoL. Beyond these topics, information about inflammatory mediator measurements in blood samples and gingival crevicular fluid, was reported.

Eighteen studies were cross-sectional in nature, only a study by Miranda et al. [32, 33] had a prospective cohort study design. At baseline, adolescents with and without JIA were examined for clinical and immunological variables of periodontal inflammation, and two years later a subgroup, eighteen adolescents with JIA and fourteen without JIA, were re-examined. Another study of Lehtinen et al. [24], distributed coded radiographs at random between different examination sessions, so the only examiner was blinded for the information of whether the radiographs belonged to participants with JIA or healthy controls.

All included studies reported age of children and adolescents with JIA and of those without JIA. However, the degree of matching varied. Although no study of true case-control design was included in the review, two studies showed controls matched for age, gender and ethnicity [22, 39]. Another characteristic of included studies was a distinct variation of sample sizes. In some studies, the sample size was too low to justify any result evidence. Beforehand sample size calculation was uncommon, as only one article [29] described this. In most studies the number of examiners was low, usually one. With some exceptions [22, 24, 31, 33], no description of calibration of examiners or reliability values were included. Bitewing radiographs were reported by only two research groups $[25,26,32]$.

\section{Dental caries}

Eight of the included articles described dental caries, but with divergent results. Both Ahmed et al. and Welbury et al. [22, 31] documented that a significantly larger proportion of children with JIA had untreated caries compared with healthy peers. Welbury et al. [31] also documented that individuals with JIA, had a higher burden of caries than individuals without JIA; among children, more primary teeth decayed, filled or extracted and among adolescents, predominantly more dental decay (D: decayed component in the DMFT). In contrast, the study of Santos et al. [29] revealed caries in primary teeth to be more frequent among healthy children than among children with JIA. Five articles [23, 25, 27, 30, 39] did not show any significant difference between the children and adolescents with and without JIA when subgroups were not included. The way of reporting caries varied from untreated caries, dmft, DMFT, D to caries prevalence of affected individuals. The use of diagnostic tools also varied. Both the World health Organization (WHO) criteria [45] and the British Association for the Study of Community Dentistry (BASCD) standardized criteria [80] were used, while some studies did not report the caries diagnostic tool used. Only one study by Leksell et al. [25], reported enamel caries.

\section{Quantitative synthesis}

Three cross-sectional studies (three publications) were included in the analysis to evaluate the association between caries in primary teeth and JIA (71 children with JIA and 141 total participants). We observed no difference in summary mean dmft scores between JIA and those who did not experience JIA $(-1.16,95 \% \mathrm{CI},-3.02-$ $\left.0.71, \mathrm{I}^{2}=87.9 \%, p_{\text {heterogenity }}=<0.0001\right)($ Fig. 1$)$.

Six cross-sectional studies (three same publications as used above as they comprised of data from both primary- and of permanent teeth, and three other publications) were included in the analyses to evaluate the association between caries in permanent teeth and JIA (162 children and adolescents with JIA and 320 total participants). We observed no difference in summary mean DMFT score between children and adolescents with JIA and those who did not experience JIA $(-0.08$, $95 \% \mathrm{CI},-0.42$ to $0.26, \mathrm{I}^{2}$ statistic $=0.0 \%, \%, p_{\text {heterogenity }}=$ 0.95) (Fig. 2).

No evidence of publication bias with Egger's test $\left(P_{\mathrm{dmft}}=0.27, P_{\mathrm{DMFT}}=0.78\right)$ or with Begg's test was found $\left(P_{\mathrm{dmft}}=0.98, P_{\mathrm{DMFT}}=0.45\right)$ (Additional file 6: Figure. S2 and Additional file 7: Figure. S3). However, because of the small number of studies and small sample size of included studies, the results from these formal tests should not be inferred with great reliability.

\section{Plaque, gingivitis and periodontitis}

The oral health descriptors most often reported were dental plaque and signs of periodontal inflammation (gingival bleeding and bleeding on probing, probing depth $\geq 2 \mathrm{~mm}$, clinical attachment loss, pocket depths etc.). There were studies focusing on oral hygiene and dental plaque $[23,25,28,31]$ showing a statistically higher Plaque Index (PI) or Simplified Oral Hygiene 


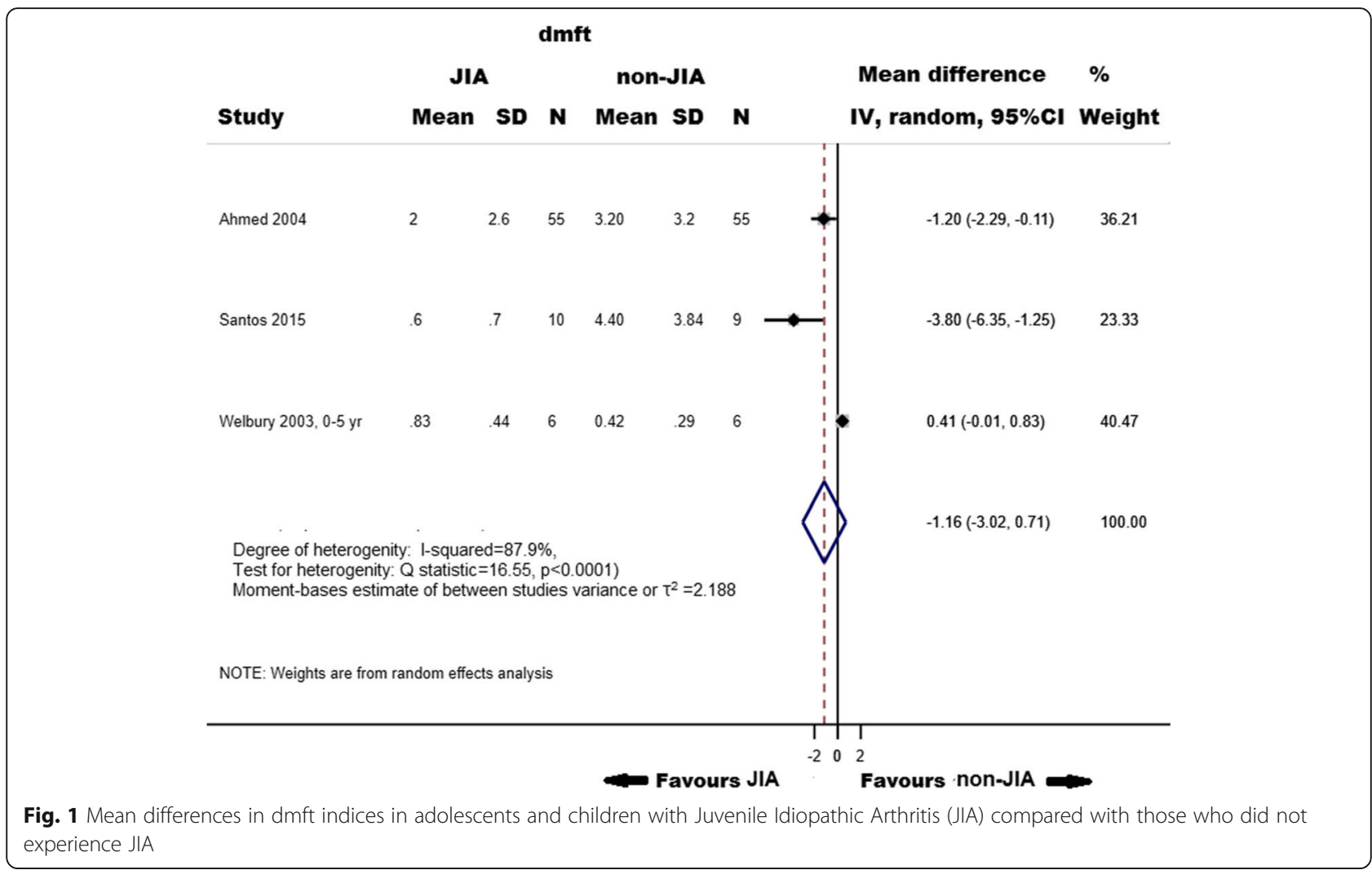

Index (OHI-S) in the JIA group compared with those without JIA. Other studies [22, 26, 27, 29, 30, 39] did not find this association. Additionally, Leksell et al. found calculus to be significantly more prevalent in individuals with JIA compared with those who did not experience JIA [25]. Many articles also documented poorer periodontal status among children and adolescents with JIA; more gingival inflammation and gingival bleeding $[22,29,31]$, bleeding upon probing [25], deeper probing depth $[25,26]$ and periodontal attachment loss $[26,28]$. However, not all articles documented differences in periodontal status when comparing individuals with JIA with healthy counterparts [23, 30, 39].

\section{Developmental enamel defects and ulcers}

The only study reporting developmental enamel defect [22], found the condition more frequent among children with JIA than among healthy peers, but the sample size was too small to draw any reliable conclusion. Another study focused on oral ulceration [25] and found five out of forty-one children with JIA to be affected, but only one out of forty-one children in the group without JIA.

\section{Dental maturation}

Two of the included studies investigated the status of dental maturation and found divergent results. By examining orthopantomograms (OPG), Lehtinen A et al. [24] in 2000 documented more advanced dental development in children with juvenile rheumatoid arthritis (JRA) compared with healthy peers, while Ley et al. [40] nine years later assessed dental maturity in children and adolescents with JIA to be within the norms of healthy peers.

TMD

TMJ arthritis (active inflammation of the joint), TMJ involvement (osteoarthritis or growth disturbances as a result of TMJ arthritis) [81] and TMD were coherently reported more frequently among children with JIA than among healthy peers [35-38].

\section{OHRQoL}

In the study of Leksel et al. [38], orofacial symptoms influenced more often the daily life in a group of children with JIA compared to the healthy individuals. Santos et al. [29] also compared oral health-related quality of life in children and adolescents with JIA and healthy peers. The instrument Brazilian SF:13- B-PCPQ instrument was used and consisted of thirteen items related to oral symptoms, functional limitations and well-being. In the different groups, most caregivers indicated that the oral health status of their children and adolescents had little or no effect on their well-being, and no significant differences between the groups were found. 


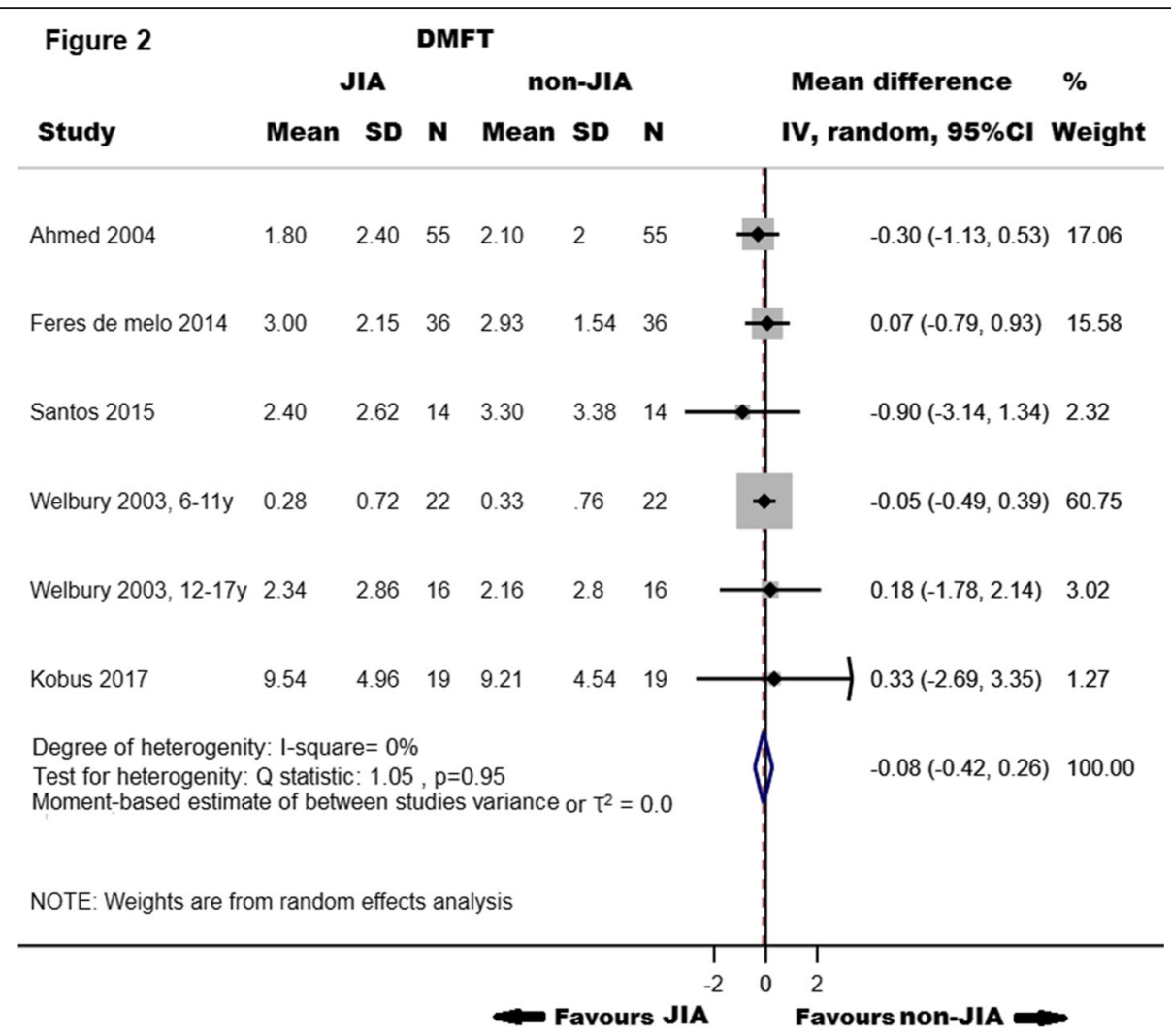

Fig. 2 Mean differences in DMFT indices in adolescents and children with Juvenile Idiopathic Arthritis (JIA) compared with those who did not experience JIA

For the present review Additional file 3: Table S3 presents the critical appraisal of the included studies while Additional file 4: Table S4 shows a completed 2009 PRISMA check list.

\section{Influence by JIA activity and severity}

The majority of the studies contained some clinical information about the JIA status of the participants. Examples of descriptors were JIA category, disease activity, anti-rheumatic medication, JIA onset and functional impairment. Pugliese et al. [27] showed that wellestablished JIA disease and validated activity scores (Juvenile Arthritis Disease Activity Score (JADAS), physician global assessment of disease activity visual analogue scale (PhysglobVAS) and parent/patient global assessment of well-being VAS (PglobVAS) were positively correlated with the DMT score. Other scores; Escola Paulista de Medicina Range of Motion Scale (EPMROM) and Child Health Assessment Questionnaire (CHAQ) were positively correlated with Gingival Index (GI), PhysglobVAS was correlated with PI, and Pediatric Quality of Life Inventory 4.0 (PedsQL) parents was correlated with Gingival Bleeding Index (GBI). Savioli et al. [30] found that a subgroup of children with polyarticular RF negative JIA, had a statistically higher GBI and
DMFT index than controls. Also a subgroup of children with three to eight affected joints in upper extremities, had significantly higher bleeding index than controls [30]. Self-reported pain or weakness in the hand when tooth brushing was documented in the study of Leksell et al. [25] as a problem among children with JIA. A significantly higher proportion of children with JIA compared with children without JIA, also answered that they did not brush their teeth when they did not feel well. Additionally, Miranda et al. reported a significantly higher mean number of joints with limitation of movements (LOM) in adolescents with two $\mathrm{mm}$ or more attachment loss (AL) than in adolescents without AL [26]. It is also worth mentioning the findings of Miranda et al. [32] of increased serum IL-18 and IL-1 $\beta$ in adolescents of JIA subgroups with AL, suggesting that $\mathrm{AL}$ might be associated with systemic inflammatory response. Low sample sizes, however, made it difficult to draw conclusions.

For children and adolescents with JIA, medication constitutes a substantial part of life which in turn may impact on oral health. Leksell et al. showed that children taking anti-TNF $\alpha$ had a higher frequency of sites with increased probing depth compared to children not taking this medicine [25]. Reichert et al. [28], comparing 
adolescents with JIA who took non-steroidal antiinflammatory drugs (NSAIDs) with other JIA peers who did not take drugs, found a significant decreased mean value for modified sulcular bleeding index in the NSAID group. The frequency of cyclosporine medication, assessed by Pugliese et al. [27], was found to be higher in JIA patients with gingivitis compared with those without gingivitis. It is important to bear in mind that it is very difficult to differentiate the effect of single drugs from the effect of the disease activity with associated systemic inflammatory response in these studies. Children on anti-TNF $\alpha$ or cyclosporine probably have a more severe disease than children without these drugs, and differences in oral health between groups with or without a certain drug may be due to the disease severity and not the drug itself. Miranda et al. [33] in a follow-up study of adolescents with JIA documented that anti-rheumatic treatment resulting in reduction in disease activity clearly and positively influenced the periodontal status. After two years, no clinical or laboratory differences in periodontal inflammation could be documented between the adolescents with and without JIA. Pugliese et al. [27] documented that adolescents with an increased $\mathrm{C}$ - reactive protein (CRP) showed a higher mean clinical attachment loss (CAL) compared with those with normal CRP values.

All these reports about medication shared the previously reported problem of lacking adequate sample sizes for evidence. The comparisons were also hampered by the fact that the disease status of children and adolescents with JIA taking a certain drug were not the same as children and adolescents with JIA who did not take the drug.

\section{Discussion}

The aim of this systematic review was to investigate the relationship between oral health measures and OHRQoL among children and adolescents with JIA compared with peers without JIA. The present systematic review and meta-analysis includes mostly studies with crosssectional design and the overall qualitative assessment of these studies was found to be low. As a wealth of information was reported, interpretation of the data needed a clear and thorough reporting of methodology, quality and bias [82]. Tables 1 and 2 constituted the quality evidence basis when answering the research questions of the article. For dental caries, also caries meta-analysis (a quantitative method to combine data) was feasible.

Reviews published more than a decade ago have concluded that oral health in children with JIA is poor [13, 14]. However, the articles examined in these reviews were from the 1970s and the 1980s. Conclusions from this review based on more recent research on the caries situation among children and adolescents with JIA, have not been easy to draw. Due to insufficient sample size in the study of Santos et al. [29], the statistically lower dmft value among children with JIA compared with healthy peers, is not compact. The opposite conclusion drawn by Welbury et al. [31], showing a higher mean $\mathrm{dmft}$ among 0-11-year-olds with JIA and a higher D component among 12-17-year-olds with JIA, is probably a more reliable finding due to higher sample sizes and a calibrated examiner. Nevertheless, as the total sample included many subgroups, the exact number in the two subgroups reported was not reassuring; the youngest subgroup of both individuals with and without JIA included 46 individuals, the older subgroup 32. Additionally, bitewing radiographs were not included in the caries examination, which actually meant an underscoring of approximal caries lesions and of total caries experience [83]. However, as both cases and controls were examined without bitewing radiographs, it was not necessary to take into account any bias in the comparison.

Although the present review evaluated eight articles with caries as subject, we could not conclude that caries was more prevalent among children and adolescents with JIA than among healthy peers. The findings from this meta-analysis on dental caries suggest no significant mean difference in dmft or DMFT between JIA affected individuals and not. One of the explanations for a possible improved caries status in individuals with JIA during the later years, might be the development of a more effective overall treatment of JIA [84]. Another explanation is the increased focus on oral health in JIA, including the development of other sweeteners and sugar alternatives used in medicines e.g. in NSAID mixtures [16].

The finding that plaque, gingivitis and periodontitis were more common among children and adolescents with JIA than among those without JIA, constituted a consistent trait in the present review. The fact that so many studies drew this conclusion increased the quality of evidence supporting this result. Unfortunately, it was not possible to perform meta-analysis due to inconsistency of outcome definitions for periodontitis across the studies.

The present review lacked studies with focus on erosive wear, a condition which in later years has been reported to be as commonly distributed as caries in some groups of adolescents $[85,86]$. Only one study reported on enamel defects [22], but it had very small sample size, so reliable information about the prevalence of this oral condition is still lacking. To the question of whether dental maturation was more advanced among patients with JIA than among healthy peers, there was no clear answer. The OPG radiographs in the study of Lethinen et al. [24], dating from the late 1960s to the early 1980s, 
were therefore too old to represent today's patients, and the study of Ley et al. [87] instead of matched controls, compared the findings in children with JIA with normative values obtained from healthy Canadian, German and Dutch children. Conclusively, for dental erosive wear, enamel defects and dental maturation, there is no scientific evidence to answer the posed research questions.

Concerning TMJ arthritis and TMJ involvement, the present review consolidated the literature reporting these conditions to be more common in children and adolescents with JIA than in healthy counterparts [88]. However, not all the five included articles that described this topic had sufficient sample size to give reliable results [22, 35-38], but a higher frequency of surface flattening of the condylar head in children with JIA versus those without JIA, seemed to be a valid radiological feature, reported by Shwaikh et al. [35]. Furthermore, TMD and structural TMJ changes were found to be more prevalent in children with JIA than in healthy peers [38], and when comparing OHRQoL in the two groups, these were poorest among the children with JIA [38]. This was not a surprising result, taking into account that oral health definition includes all functioning without feeling pain or discomfort.

In order to answer the research question, whether OHRQoL only due to oral diseases/conditions restricted to the oral cavity is more common among those with JIA than those without, more studies related to this topic are needed. Only one study was included in the review concerning this topic: Santos et al. [29] documented that oral health status had little or no effect on well-being among both individuals with JIA and those without JIA.

To be able to respond to the second research question, whether the activity and severity of JIA had any impact on the prevalence of oral and TMJ diseases or oral conditions, larger sample sizes are needed before reliable answers can be given.

\section{Strengths and limitations}

The strength when comparing children and adolescents with JIA with those without JIA, is that the overall oral health outcomes were taken into account and discussed elaborately. Another strength of the study was the adoption of PRISMA protocol [41] and the use of modified Newcastle-Ottawa Scale to comprehensively evaluate and assess the methodological quality of the selected studies [75]. Additionally, meta-analysis was performed for studies focusing on dental caries as an outcome. However, the present. systematic review was not without limitations. Firstly, majority of the included studies were cross-sectional in nature which is tied to high risk of bias. Secondly, due to inadequate studies and inconsistency of outcome definitions, only meta-analyses regarding dental caries, not regarding other oral diseases or conditions, could be performed. Thirdly, as grey literature was excluded in the present systematic review, the comprehensiveness of the search might have been reduced and therefore should be considered as a limitation of the review [89].

\section{Conclusions}

Despite of limitations, periodontal diseases and TMD were found to be more frequent in children and adolescents with JIA compared with healthy peers. Regarding the association between the prevalence of oral and TM) diseases or oral conditions in relation to activity and severity of JIA, no solid conclusion could be drawn. This systematic review and meta-analysis concluded that more high quality research with large sample size is required in this field.

\section{Supplementary information}

Supplementary information accompanies this paper at https://doi.org/10. 1186/s12903-019-0965-4

\section{Additional file 1: Table S1. Search history}

Additional file 2: Table S2. Scale adapted after Newcastle-Ottawa Quality Assessment Scale for cross-sectional studies by Herzog et al. [75] and further modified in support of this systematic review

Additional file 3: Table S3. Scoring of risk of bias

Additional file 4: Table S4. 2009 PRISMA Check list

Additional file 5: Figure S1. PRISMA flow diagram of review

Additional file 6: Figure S2. Funnel plot for assessment of bias in the mean difference of $\mathrm{dmft}$ of primary dentition studies between children with JIA and controls ( $n=3$ studies)

Additional file 7: Figure S3. Funnel plot for assessment of bias in the mean difference of DMFT score of permanent dentition studies between children and adolescents with JIA and controls ( $n=6$ studies)

\section{Abbreviations \\ AL: Attachment loss; BASCD: British Association for the Study of Community Dentistry; CAL: Clinical attachment loss; CHAQ: Child Health Assessment Questionnaire; CRP: C - reactive protein; CTs: Controlled clinical trials; D: Decayed component in the DMFT; DMFT: Decayed/missed/filled permanent teeth; dmft: Decayed/missed/filled primary teeth; EPM- ROM: Escola Paulista de Medicina Range of Motion Scale; GBI: Gingival Bleeding Index; GI: Gingival Index; ILAR: International League of Associations of Rheumatology; JADAS: Juvenile Arthritis Disease Activity Score; JIA: Juvenile idiopathic arthritis; JRA: Juvenile rheumatoid arthritis; LOM: Limitation of movements; NOS: Newcastle - Ottawa Scale; NSAID: Non- steroidal anti-inflammatory drug; OHI-S: Simplified Oral Hygiene Index; OHRQoL: Oral health-related quality of life; OPG: Orthopantomograms; PedsQL: Pediatric Quality of Life Inventory 4.0; PglobVAS: Parent/patient global assessment of well-being VAS; PhysglobVAS: Physician global assessment of disease activity visual analogue scale; PI: Plaque Index; PICOS: Participants, interventions, comparators, and study design; PRISMA: Preferred reporting items for systematic reviews and meta-analyses; QoL: Quality of life; RA: Rheumatic arthritis; RCTs: Randomised controlled trials; RF: Rheumatoid factor; TMD: Temporomandibular disorder; TMJ: Temporomandibular joint; WHO: World health Organization}




\section{Authors' contributions}

Two authors (MSS and AB) independently read and assessed the abstracts and selected articles in full text in this systematic review. MSS: contributed substantially to the manuscript writing. AS: performed meta-analysis statistics. MR: was in charge of the medical part. EGG, LC, AR, JF, ANÅ, AS, KL, XS, AJF, PF: all actively provided valuable comments. All authors have read and approved the final manuscript.

\section{Author's information}

${ }^{1}$ Department of Clinical Dentistry, University of Bergen, Norway. ${ }^{2}$ Center for Oral Health Services and Research, Mid-Norway (TkMidt), Trondheim, Norway. ${ }^{3}$ Department of Oral and Maxillofacial Surgery, Haukeland University Hospital, Bergen, Norway. ${ }^{4}$ Section of Oral Diagnostics and Surgery, Department of Dental Medicine, Karolinska Institutet, Huddinge, Sweden. ${ }^{5}$ Department of Public health and Nursing, Faculty of Medical and Health Sciences, Norwegian University of Science and Technology, Trondheim, Norway. ${ }^{6}$ Public Dental Health Service Competence Centre of Northern Norway (TkNN), Tromso, Norway. ${ }^{7}$ Department of Clinical Medicine, Faculty of Health Sciences, UiT, The Arctic University of Norway, Tromso, Norway. ${ }^{8}$ Department of Otorhinolaryngology, Division of Oral and Maxillofacial Surgery, University Hospital North Norway. ${ }^{9}$ Department of Clinical and Molecular Medicine, NTNU - Norwegian University of Science and Technology, Trondheim, Norway. ${ }^{10}$ Department of Pediatrics, St. Olavs Hospital, Trondheim, Norway. ${ }^{11}$ Oral Health Centre of Expertise in Western Norway- Hordaland, Norway.

\section{Funding}

Not applicable.

\section{Availability of data and materials}

All data generated and analysed during this study are included in this published article [and its supplementary information files].

\section{Ethics approval and consent to participate}

Not applicable.

\section{Consent for publication \\ Not applicable.}

\section{Competing interests}

The authors declare that they have no competing interests.

\section{Author details}

'Department of Clinical Dentistry, Pediatric Dentistry, The Faculty of Medicine, University of Bergen, Norway, Årstadveien 19, N-5009 Bergen, Norway. ${ }^{2}$ Center for Oral Health Services and Research, Mid-Norway (TkMidt), Trondheim, Norway. ${ }^{3}$ Department of Oral and Maxillofacial Surgery, Haukeland University Hospital, Bergen, Norway. ${ }^{4}$ Section of Oral Diagnostics and Surgery, Department of Dental Medicine, Karolinska Institutet, Huddinge, Sweden. ${ }^{5}$ Department of Public health and Nursing, Faculty of Medical and Health Sciences, Norwegian University of Science and Technology, Trondheim, Norway. ${ }^{6}$ Public Dental Health Service Competence Centre of Northern Norway (TkNN), Tromso, Norway. ${ }^{7}$ Department of Clinical Medicine, Faculty of Health Sciences, UiT, The Arctic University of Norway, Tromso, Norway. ${ }^{8}$ Department of Otorhinolaryngology, Division of Oral and Maxillofacial Surgery, University Hospital North, Tromso, Norway. ${ }^{9}$ Department of Clinical and Molecular Medicine, NTNU - Norwegian University of Science and Technology, Trondheim, Norway. ${ }^{10}$ Department of Pediatrics, St. Olavs Hospital, Trondheim, Norway. ${ }^{11}$ Oral Health Centre of Expertise in Western Norway- Hordaland, Trondheim, Norway.

Received: 8 July 2019 Accepted: 21 November 2019 Published online: 19 December 2019

\section{References}

1. Gabriel SE, Michaud K. Epidemiological studies in incidence, prevalence, mortality, and comorbidity of the rheumatic diseases. Arthritis Res Ther. 2009;11(3):229

2. Riise OR, Handeland KS, Cvancarova M, Wathne KO, Nakstad B, Abrahamsen TG, et al. Incidence and characteristics of arthritis in Norwegian children: a population-based study. Pediatrics. 2008;121(2):e299-306.
3. Thierry S, Fautrel B, Lemelle I, Guillemin F. Prevalence and incidence of juvenile idiopathic arthritis: a systematic review. Joint Bone Spine. 2014;81(2):112-7.

4. Berntson L, Andersson Gare B, Fasth A, Herlin T, Kristinsson J, Lahdenne P, et al. Incidence of juvenile idiopathic arthritis in the Nordic countries. A population based study with special reference to the validity of the ILAR and EULAR criteria. J Rheumatol. 2003;30(10):2275-82.

5. Petty RE, Southwood TR, Manners P, Baum J, Glass DN, Goldenberg J, et al. International league of associations for rheumatology classification of juvenile idiopathic arthritis: second revision, Edmonton, 2001. J Rheumatol. 2004;31(2):390-2.

6. Lien G, Flato B, Haugen M, Vinje O, Sorskaar D, Dale K, et al. Frequency of osteopenia in adolescents with early-onset juvenile idiopathic arthritis: a long-term outcome study of one hundred five patients. Arthritis Rheum. 2003;48(8):2214-23.

7. Twilt M, Mobers SM, Arends LR, ten Cate R, van Suijlekom-Smit L. Temporomandibular involvement in juvenile idiopathic arthritis. J Rheumatol. 2004;31(7):1418-22.

8. Carty SM, Snowden N, Silman AJ. Should infection still be considered as the most likely triggering factor for rheumatoid arthritis? Ann Rheum Dis. 2004; 63(Suppl 2):ii46-i9.

9. Verma D, Garg PK, Dubey AK. Insights into the human oral microbiome. Arch Microbiol. 2018;200(4):525-40.

10. Jia G, Zhi A, Lai PFH, Wang G, Xia Y, Xiong Z, et al. The oral microbiota - a mechanistic role for systemic diseases. Br Dent J. 2018;224(6):447-55.

11. Pine $C M$, Harris RV, Burnside G, Merrett MC. An investigation of the relationship between untreated decayed teeth and dental sepsis in 5-yearold children. Br Dent J. 2006;200(1):45-7 discussion 29.

12. Zhang $X$, Zhang $D$, Jia $H$, Feng $Q$, Wang $D$, Liang $D$, et al. The oral and gut microbiomes are perturbed in rheumatoid arthritis and partly normalized after treatment. Nat Med. 2015;21(8):895-905.

13. Walton AG, Welbury RR, Thomason JM, Foster HE. Oral health and juvenile idiopathic arthritis: a review. Rheumatol (Oxford) 2000;39(5):550-5.

14. Synodinos PN, Polyzois I. Oral health and orthodontic considerations in children with juvenile idiopathic arthritis: review of the literature and report of a case. J Ir Dent Assoc. 2008;54(1):29-36.

15. Maguire A, Rugg-Gunn AJ. Medicines in liquid and syrup form used longterm in paediatrics: a survey in the northern region of England. Int J Paediatr Dent. 1994;4(2):93-9.

16. Maguire A. Dental health. In: O'Donnell K, Kearsley M, editors. Sweeteners and sugar alternatives in food technology 2012. p. 34-5.

17. Weiss PF, Arabshahi B, Johnson A, Bilaniuk LT, Zarnow D, Cahill AM, et al. High prevalence of temporomandibular joint arthritis at disease onset in children with juvenile idiopathic arthritis, as detected by magnetic resonance imaging but not by ultrasound. Arthritis Rheum. 2008;58(4):1189-96.

18. Fjeld M, Arvidsson L, Stabrun A, Birkeland K, Ta L, Øgaard B. Average craniofacial development from 6 to 35 years of age in a mixed group of patients with juvenile idiopathic arthritis. Acta Odontol Scand. 2009;67:153-60.

19. Glick M, Monteiro da Silva O, Seeberger GK, Xu T, Pucca G, Williams DM, et al. FDI vision 2020: shaping the future of oral health. Int Dent J. 2012;62(6):278-91.

20. Frid P, Nordal E, Bovis F, Giancane G, Larheim TA, Rygg M, et al. Temporomandibular joint involvement in association with quality of life, disability, and high disease activity in juvenile idiopathic arthritis. Arthritis Care Res (Hoboken). 2017;69:677-86.

21. Rahimi H, Twilt M, Herlin T, Spiegel L, Pedersen TK, Kuseler A, et al. Orofacial symptoms and oral health-related quality of life in juvenile idiopathic arthritis: a two-year prospective observational study. Pediatr Rheumatol Online J. 2018;16(1):47.

22. Ahmed N, Bloch-Zupan A, Murray KJ, Calvert M, Roberts GJ, Lucas VS. Oral health of children with juvenile idiopathic arthritis. J Rheumatol. 2004;31(8):1639-43.

23. Feres de Melo AR, Ferreira de Souza A, de Oliveira PB, Leite MF. Clinical oral and salivary parameters of children with juvenile idiopathic arthritis. Oral Surg Oral Med Oral Pathol Oral Radiol. 2014;117(1):75-80.

24. Lehtinen A, Oksa T, Helenius $H$, Ronning O. Advanced dental maturity in children with juvenile rheumatoid arthritis. Eur J Oral Sci. 2000;108(3):184-8.

25. Leksell E, Ernberg M, Magnusson B, Hedenberg-Magnusson B. Intraoral condition in children with juvenile idiopathic arthritis compared to controls. Int J Paediatr Dent. 2008;18(6):423-33. 
26. Miranda LA, Fischer RG, Sztajnbok FR, Figueredo CM, Gustafsson A. Periodontal conditions in patients with juvenile idiopathic arthritis. J Clin Periodontol. 2003;30(11):969-74.

27. Pugliese C, van der Vinne RT, Campos LM, Guardieiro PR, Saviolli C, Bonfa E, et al. Juvenile idiopathic arthritis activity and function ability: deleterious effects in periodontal disease? Clin Rheumatol. 2016:35(1):81-91.

28. Reichert S, Machulla HK, Fuchs C, John V, Schaller HG, Stein J. Is there a relationship between juvenile idiopathic arthritis and periodontitis? J Clin Periodontol. 2006;33(5):317-23.

29. Santos D, Silva C, Silva M. Oral health and quality of life of children and adolescents with juvenile idiopathic arthritis according to their caregivers' perceptions. Spec Care Dentist. 2015;35(6):272-8.

30. Savioli C, Silva CA, Ching LH, Campos LM, Prado EF, Siqueira JT. Dental and facial characteristics of patients with juvenile idiopathic arthritis. Rev Hosp Clin Fac Med Sao Paulo. 2004;59(3):93-8.

31. Welbury RR, Thomason JM, Fitzgerald JL, Steen IN, Marshall NJ, Foster HE. Increased prevalence of dental caries and poor oral hygiene in juvenile idiopathic arthritis. Rheumatol (Oxford). 2003;42(12):1445-51.

32. Miranda LA, Fischer RG, Sztajnbok FR, Johansson A, Figueredo CM, Gustafsson A. Increased interleukin-18 in patients with juvenile idiopathic arthritis and early attachment loss. J Periodontol. 2005;76(1):75-82.

33. Miranda LA, Braga F, Fischer RG, Sztajnbok FR, Figueredo CM, Gustafsson A. Changes in periodontal and rheumatological conditions after 2 years in patients with juvenile idiopathic arthritis. J Periodontol. 2006:77(10):1695-700.

34. Maspero C, Giannini L, Galbiati G, Prevedello C, Farronato G. Periodontal conditions in juvenile idiopatic arthritis. Minerva Stomatol. 2017;66(2): 43-50.

35. Al-Shwaikh H, Urtane I, Pirttiniemi P, Pesonen P, Krisjane Z, Jankovska I, et al. Radiologic features of temporomandibular joint osseous structures in children with juvenile idiopathic arthritis. Cone beam computed tomography study. Stomatologija. 2016;18(2):51-60.

36. Abdul-Aziez OA, Saber NZ, El-Bakry SA, Mohammad AA, Abdel-Maksud SS, Ali Y. Serum S100A12 and temporomandibular joint magnetic resonance imaging in juvenile idiopathic arthritis Egyptian patients: a case control study. Pak J Biol Sci. 2010;13(3):101-13.

37. Mohammed Y, Saeed O, Zaghloul N, Samer S, Mahmud SA, A. Juvenile idiopathic arthritis and the temporomandibular joint. Alexandria J Med. 2012;48:123-9.

38. Leksell E, Ernberg M, Magnusson B, Hedenberg-Magnusson B. Orofacial pain and dysfunction in children with juvenile idiopathic arthritis: a case-control study. Scand J Rheumatol. 2012;41(5):375-8.

39. Kobus A, Kierklo A, Zalewska A, Kuzmiuk A, Szajda SD, Lawicki S, et al. Unstimulated salivary flow, $\mathrm{pH}$, proteins and oral health in patients with juvenile idiopathic arthritis. BMC Oral Health. 2017;17(1):94.

40. Ley M, Landau H, Mueller-Hartwich R, Minden K, Roth J. Dental maturation in children and adolescents with juvenile idiopathic arthritis. Akt Rheumatol. 2009;34:209-12.

41. Moher D, Liberati A, Tetzlaff J, Altman DG, Group P. Preferred reporting items for systematic reviews and meta-analyses: the PRISMA statement. PLoS Med. 2009;6(7):e1000097.

42. Cleaton-Jones P, Hargreaves JA, Fatti LP, Chandler HD, Grossman ES. Dental caries diagnosis calibration for clinical field surveys. Caries Res. 1989;23(3):195-9.

43. Franco E, Saunders CP, Roberts GJ, Suwanprasit A. Dental disease, caries related microflora and salivary IgA of children with severe congenital cardiac disease: an epidemiological and oral microbial survey. Pediatr Dent. 1996;18(3):228-35

44. Ainamo J. An epidemiological index of developmental defects of dental enamel (DDE index). Int Dent J. 1982;32:157-67.

45. WHO. Oral health surveys. Basic methods, 4th edition. Geneva: 1997; Report. 1997.

46. WHO. Oral health surveys. Geneva: Basic methods; 1987.

47. Greene JC, Vermillion JR. The simplified Oral hygiene index. J Am Dent Assoc. 1964;68:7-13.

48. Loe $\mathrm{H}$, Silness J. Periodontal disease in pregnancy. I. Prevalence and severity. Acta Odontol Scand. 1963;21:533-51.

49. Demirjian A, Goldstein H, Tanner JM. A new system of dental age assessment. Hum Biol. 1973;45(2):211-27.

50. Demirjian A, Goldstein H. New systems for dental maturity based on seven and four teeth. Ann Hum Biol. 1976;3(5):411-21.
51. Modéer T, Barr M, Dahllof G. Periodontal disease in children with Down's syndrome. Scand J Dent Res. 1990;98(3):228-34.

52. Ainamo J, Bay I. Problems and proposals for recording gingivitis and plaque. Int Dent J. 1975:25(4):229-35.

53. O'Leary T. Periodontal screen examination. J Periodontol. 1967;38:617-24.

54. Armitage G. American academy of periodontology. Periodontol record Ann Periodontol. 1999;38:617-24.

55. Pedersen TK, Jensen JJ, Melsen B, Herlin T. Resorption of the temporomandibular condylar bone according to subtypes of juvenile chronic arthritis. J Rheumatol. 2001;28(9):2109-15.

56. Lange D, Plagmann $H$, Eenboom A, Promesberger A. Klinische Bewertungverfahren zur Objektivierung der Mundhygiene. Dtsch Zahnarztl Z. 1977;32:44-7.

57. Muhlemann HR, Son S. Gingival sulcus bleeding--a leading symptom in initial gingivitis. Helv Odontol Acta. 1971;15(2):107-13.

58. Organization WH. Epidemiology, etiology, and prevention of periodontal disease. WHO Technical Report. 1978;621:16-7.

59. Jokovic A, Locker D, Stephens M, Kenny D, Tompson B, Guyatt G. Measuring parental perceptions of child oral health-related quality of life. J Public Health Dent. 2003;63(2):67-72.

60. O'Leary T. The periodontal screening examination. J Periodontol 1967;38(6): Suppl:617-624.

61. Helkimo $H$. Studies on function and dysfunction of the masticatory system. II. Index for anamnestic dysfunction and occlusal state. Swed Dent J. 1974; 67:101-19.

62. Mitropoulos C, Pitts N, Deery C. British Association for the Study of community dentistry criteria for the standard assessment of dental health. Dundee: University of Dundee. BASCOD Trainers Pack for Caries Prevalence; 1992.

63. Silness J, Loe H. Periodontal disease in pregnancy. li. Correlation between Oral hygiene and periodontal Condtion. Acta Odontol Scand. 1964;22:121-35.

64. Turesky S, Gilmore ND, Glickman I. Reduced plaque formation by the chloromethyl analogue of victamine C. J Periodontol. 1970;41(1):41-3.

65. Ahmad M, Hollender L, Anderson Q, Kartha K, Ohrbach R, Truelove EL, et al. Research diagnostic criteria for temporomandibular disorders (RDC/TMD): development of image analysis criteria and examiner reliability for image analysis. Oral Surg Oral Med Oral Pathol Oral Radiol Endod. 2009;107(6):844-60.

66. Billiau AD, Hu Y, Verdonck A, Carels C, Wouters C. Temporomandibular joint arthritis in juvenile idiopathic arthritis: prevalence, clinical and radiological signs, and relation to dentofacial morphology. J Rheumatol. 2007;34(9):1925-33.

67. Agerberg G. Maximal mandibular movements in children. Acta Odontol Scand. 1974;32:147-59.

68. Kuseler A, Pedersen TK, Gelineck J, Herlin T. A 2 year followup study of enhanced magnetic resonance imaging and clinical examination of the temporomandibular joint in children with juvenile idiopathic arthritis. J Rheumatol. 2005;32(1):162-9.

69. Bakke M, Zak M, Jensen BL, Pedersen FK, Kreiborg S. Orofacial pain, jaw function, and temporomandibular disorders in women with a history of juvenile chronic arthritis or persistent juvenile chronic arthritis. Oral Surg Oral Med Oral Pathol Oral Radiol Endod. 2001;92(4):406-14.

70. Nilsson IM, Drangsholt M, List T. Impact of temporomandibular disorder pain in adolescents: differences by age and gender. J Orofac Pain. 2009:23(2):115-22.

71. Arvidsson LZ, Flato B, Larheim TA. Radiographic TMJ abnormalities in patients with juvenile idiopathic arthritis followed for 27 years. Oral Surg Oral Med Oral Pathol Oral Radiol Endod. 2009;108(1):114-23.

72. Wei SH, Lang KP. Periodontal epidemiological indices for children and adolescents: I. gingival and periodontal health assessments. Pediatr Dent. 1981;3(4):353-60.

73. Demirjian A, H G, Jm T. A new system in dental age as assessment. Hum Biol. 1973;45:211-27.

74. Skeie MS, Klock KS. Dental caries prevention strategies among children and adolescents with immigrant - or low socioeconomic backgrounds- do they work? A systematic review. BMC Oral Health. 2018;18(1):20.

75. Herzog R, Alvarez-Pasquin MJ, Diaz C, Del Barrio JL, Estrada JM, Gil A. Are healthcare workers' intentions to vaccinate related to their knowledge, beliefs and attitudes? Syst rev BMC Public Health. 2013;13:154.

76. DerSimonian R, Kacker R. Random-effects model for meta-analysis of clinical trials: an update. Contemp Clin Trials. 2007;28:105-14. 
77. Higgins JP, Thompson SG. Quantifying heterogeneity in a meta-analysis. Stat Med. 2002;21:1539-58.

78. Egger M, Davey SG, Schneider M, Minder C. Bias in meta-analysis detected by a simple, graphical test. BMJ. 1997;315:629-34.

79. Begg CB, Mazumdar M. Operating characteristics of a rank correlation test for publication bias. Biometrics. 1994;50:1088-101.

80. Pitts N, Evans D, Pine CM. British Association for the Study of Community Dentistry (BASCD) diagnostic criteria for caries prevalence surveys-1996/97. Community Dent Health. 1997;14(Suppl 1):6-9.

81. Stoustrup P, Resnick CM, Pedersen TK, Abramowicz S, Michelotti A, Kuseler A, et al. Standardizing terminology and assessment for Orofacial conditions in juvenile idiopathic arthritis: international. Multidisciplinary Consens-based Recomm J Rheumatol. 2019.

82. Innes NP, Schwendicke F, Lamont T. How do we create, and improve, the evidence base? Br Dent J. 2016;220(12):651-5.

83. Anderson M A, Stecksen-Blicks C, Stenlund H, Ranggard L, Tsilingaridis G, Mejàre I. Detection of approximal caries in 5-year-old Swedish children. Caries Res. 2005;39(2):92-9.

84. Giancane G, Alongi A, Ravelli A. Update on the pathogenesis and treatment of juvenile idiopathic arthritis. Curr Opin Rheumatol. 2017;29(5):523-9.

85. Sovik JB, Tveit AB, Storesund T, Mulic A. Dental erosion: a widespread condition nowadays? A cross-sectional study among a group of adolescents in Norway. Acta Odontol Scand. 2014;72(7):523-9.

86. Isaksson H, Birkhed D, Wendt LK, Alm A, Nilsson M, Koch G. Prevalence of dental erosion and association with lifestyle factors in Swedish 20-year olds. Acta Odontol Scand. 2013

87. Ley M, Landau H, Mueller-Hartwich R, Minden K, Roth J. Entwicklung des Zahnalters bei Juveniler Idiopatischer arthritis [dental maturation in children and adolescents with juvenile idiopathic Arhtritis]. Akt Rheumatol. 2009;34:209-12.

88. Pantoja LLQ, de Toledo IP, Pupo YM, Porporatti AL, De Luca CG, Zwir LF, et al. Prevalence of degenerative joint disease of the temporomandibular joint: a systematic review. Clin Oral Investig. 2018.

89. Paez A. Gray literature: an important resource in systematic reviews. J Evid Based Med. 2017:10(3):233-40.

\section{Publisher's Note}

Springer Nature remains neutral with regard to jurisdictional claims in published maps and institutional affiliations.

Ready to submit your research? Choose BMC and benefit from:

- fast, convenient online submission

- thorough peer review by experienced researchers in your field

- rapid publication on acceptance

- support for research data, including large and complex data types

- gold Open Access which fosters wider collaboration and increased citations

- maximum visibility for your research: over $100 \mathrm{M}$ website views per year

At $\mathrm{BMC}$, research is always in progress.

Learn more biomedcentral.com/submissions 